\title{
Devam Sütü Tercihinde Etkili Faktörlerin ve Pazar Liderlerinin Marka Kişiliklerinin Analizi
}

\author{
Mehmet Sertaç Belet ${ }^{a}$, Fatma Özge Baruönü ${ }^{b}$
}

\section{Özet}

Bebek beslenmesinde anne sütünün yetersizliği durumunda takviye amaçlı kullanılan devam sütünün seçimi, dünyada ve ülkemizde pek çok ailenin gündeminde yer almaktadır. Bu çalışmanın konusu devam sütünde annelerin tercihini ve pediatristlerin devam sütü önerirken hangi unsurları dikkate aldıklarını ve pazar lideri olan markaların marka kişiliklerinin pediatristler ve anneler tarafından ne şekilde algıladığını ortaya koymaktır. İstanbul'da ikamet eden anneler ve pediatristler ile iki ayrı odak grup çalışması yapılmış, ardından 175 anne ve 125 pediatristdan oluşan örnekleme anket uygulanmıştır. Çalışma neticesinde devam sütü markalarının anneler ve çocuk pediatristleri tarafından farklı sebeplerden dolayı tercih edildiği ve pazar liderlerinin marka kişilikleri algısında ciddi farklılıklar olduğu görülmüştür.
Anahtar Kelimeler

Marka

Marka Kişiliği

Marka Tercihi

Devam Sütü

Makale Hakkında

Geliş Tarihi: 02.04.2019

Kabul Tarihi: 10.06 .2020

Doi: $10.18026 /$ cbayarsos.548354

\section{An Analysis of Factors Affecting Formula Milk Preference and Brand Personality of Market Leaders}

\begin{abstract}
The preference of formula milk to be used for reinforcement in case of inadequate breast feeding is on the agenda of many families in the world and in our country. The subject of this study is to demonstrate the preference of mothers in the formula milk and the factors that pediatricians consider when recommending formula milk to mothers and how the brand personalities of market leaders are perceived by pediatricians and mothers. Two separate focus group studies were conducted with mothers and pediatricians residing in Istanbul, followed by a survey which was applied to 175 mothers and 125 doctors. As a result of the study, it has been found that formula milk brands are preferred by mothers and pediatricians for different reasons and market leader brands have serious differences in terms of perceived brand personality.
\end{abstract}

Keywords

Brand

Brand Personality

Brand Choice

Formula Milk

\section{About Article}

Received: 02.04.2019

Accepted: 10.06 .2020

Doi: 10.18026/cbayarsos.548354 


\section{Giriş}

Günümüzde zorlu rekabet şartları firmaları hayatta kalabilmek için tüketicileriyle uzun süreli ilişkiler kurmaya ve rakiplerinden farklılaşmaya itmektedir. Bu süreçte markalaşma ihtiyacı kaçınılmazdır. Marka yaratma süreci oldukça zor, zahmetli, bedeli yüksek ve uzun zaman isteyen bir süreç olup, bu sürecin çok iyi yönetilmesi gerekmektedir. Uzun vadeli ve başarılı bir marka yaratmak, bu markayı sunmak ve marka farkındalığını oluşturmak ancak stratejik marka yönetimi ile mümkün olmaktadır. Markalaşan ürün ve hizmetler pazarda tutunabilmekte, yeni pazarlara ve marka genişlemelerine daha kolay adapte olabilmektedir (Keller, 2013). Stratejik marka yönetiminin temel araçlarından biri olan marka konumlandırma, ürünü/hizmeti seçilen pazar bölümünde marka özellikleri açısından en uygun yere yerleştirmek ve rakiplerinden ayrıştırmaktır (Altunışık vd., 2002; İslamoğlu ve Fırat, 2016) Tüketicilerin zihninde gerçekleşen konumlandırma, markaları birbirine göre göreceli olarak pozisyonlandırır ve bunu yaparken de marka kimliği ve marka kişiliği unsurlarını öncül olarak kullanır. Tüketicilerin algıladığı marka kişiliği stratejik marka yönetiminin en temel yapı taşlarından biridir.

Dünyada tüketicilerin marka kişiliği algılarıyla ilgili pek çok çalışma yapılmaktadır. Ülkemizde de pek çok farklı sektörde gerçekleştirilen marka kişiliği algısı çalışmaları ilgili markanın pazarda nasıl konumlandırıldığı konusunda bilgi vermekte hem de rakibiyle markanın arasında kişilikleri açısından benzerlikler ve farklılıklar olup olmadığını ortaya koymaya yardımcı olmaktadır. Türkiye'de bu amaçla gerçekleştirilen çalışmaları incelediğimizde telekomünikasyon (Girişken ve Giray, 2016), medikal (Köse vd., 2015), siyaset (Girişken vd, 2015), moda (Özdel ve Torlak, 2011), havayolları (Özer vd., 2012) ve üniversiteler (Doğanlı ve Bayri, 2012) gibi birçok farklı alanda marka kişiliği araştırmalarına rastlamaktayız.

Ancak, literatürde devam sütü tercihleri, devam sütü markalarının konumlandırılması ve devam sütü markalarının marka kişilikleri üzerine herhangi bir çalışma olmaması ve konunun 0-2 yaş bebek annelerini yakından ilgilendirmesi bu alanda doldurulması gerekenbir boşluk olduğuna işaret etmektedir. Bu nedenle söz konusu çalışmada annelerin devam sütü tercih ederken, pediatristlerin ise annelere bir devam sütü tavsiye ederken hangi faktörleri önemsedikleri araştırılmış, araştırma neticesinde anne ve pediatristlerin en çok tercih ettiği aynı zamanda pazar lideri de olan iki markanın marka kişilikleri algısı ölçülerek, farklılıklar ortaya konmaya çalışılmıştır.

\section{Marka ve Marka Kişiliği}

Marka, Amerikan Pazarlama Derneği'nin (AMA, 2017) sözlüğünün tanımına göre ayırt edici kendine has isim, logo, slogan, ses ve tasarım gibi imajların bütünüyle oluşturulan bir tüketici deneyimidir, bu öğelerin kullanımı ile değerleri, fikirleri hatta kişilikleri sembolize eder. Markalar, kimlikleri ve çağrışımları ile tüketici zihninde yer ettikten sonra temsil ettikleri ürün veya hizmetlerden sıyrılarak marka olarak kişilik kazanırlar. Marka çağrışımları bazen ürünü doğrudan kullanmakla, bazen de gözlemle oluşur (Hollis, 2011). Yapılan çalışmalar göstermiştir ki ürün veya hizmetle ilgili çağrışımlar ne kadar pozitif ve güçlü ise markanın sürekliliği de o derece fazladır (Keller, 2003). Marka çağrışımları on bir farklı şekilde incelenebilmektedir. Bunlar; ürün nitelikleri, müşteri faydaları, kullanım, yaşam biçimi/kişilik, müşteri, ülke/coğrafi alan, soyut unsurlar, göreceli fiyat, ünlü kişi, rakipler ve ürün grubundan 
oluşmaktadır (Aaker, 1991). Farklı şekillerde de olsa marka çağrışımlarının ortak fonksiyonu; tüketici zihninde markanın olumlu değerler ile ilişkilendirilmesi ve marka imajı için tüketicinin hazırlanmasıdır.

Satın alma kararını verecek kişiler fazla çeşitliliğin olduğu hizmet ve ürün ortamında, ürün veya hizmetin ederini belirleyemeyerek karar vermede zorlanırlar. Bu noktada marka, tüketicilere karar verme sürecinde önemli ölçüde etki eden bir faktördür. Marka tercihi, tüketicilerin alışkanlıkları veya geçmişteki deneyimlerine bağlı olarak rakip markaların içinden bir markayı seçme davranışı sergilemesidir (Aktuğlu ve Temel, 2006). Marka tercihini, isteğin içeriği, isteğin niteliği, marka algısı, marka bilinirliği, marka kişiliği gibi unsurlar etkiler. Tüketiciler bir ürünü veya hizmeti satın alırken markanın/ürünün kendilerine kazandıracağı somut faydaların yanı sıra mevkii ve itibar gibi soyut faydalarını da dikkate alarak seçim yaparlar. (Aktuğlu, 2004:36).

Ürün veya hizmetlerini markalarıyla farklılaştırmayı isteyen markaların konumlandırma çalışmaları yapmaları elzemdir. Marka konumlandırma, firmaların ürünlerini pazarlayacağı hedef pazarda, potansiyel müşteriye sunacağı ürün veya hizmetin nasıl olacağının ve alternatif markalar arasındaki yerinin belirlenmesidir (Bradley, 1995). Buluç'a (2013) göre marka konumlandırması sürecinde önem verilmesi gereken dört farklı nokta bulunmaktadır. Bunlardan ilki tüketicinin zihninde oluşturulmak istenen konumlandırmanın kolay anlaşılır ve açı olmasıdır. İkinci olarak bu konumlandırmanın tutarlı bir şekilde hedef kitleye iletilebilmesidir. Üçüncü olarak konumlandırma fikrinin rakiplerden farklılık yarattığı iddia edilen değerinin markanın gerçek güçlerinden alınmasıdır. Son olarak markanın, rakipleriyle rekabet edebileceği, gerçekten farklı konulara odaklı bir konumlandırma fikrinin oluşturulması gereğidir. Sonuç olarak konumlandırma, işletmelerin rekabetçi güç elde etmeleri, sürdürülebilir olmaları için markalarını rakiplerine göre tüketicilerin zihninde nasıl farklılaştırdığ 1 gerçeğine dayanmaktadır.

Tüketicilerin zihninde gerçekleşen konumlandırma, markaları birbirini baz alarak pozisyonlandırır; bunu yaparken de marka kimliği ve marka kişiliği unsurlarından yararlanır. Tüketicilerin ilgili markaya dair algıladığı marka kişiliği, marka tarafından yıllar içinde tüm tutundurma faaliyetlerinin bütünleşik ve tutarlı bir şekilde tüketiciye aktarılması sonucu tüketici zihninde yer etmiştir. Keller'e (2003) göre, marka kişiliği, insana ait kavramların markaya uygulanmasıdır. Bir diğer tanıma göre ise marka kişiliği, "markayla eşleştirilebilen insani kavramlar"' dır (Aaker, 1997:347). Marka kişiliği; satın alan kişi ve ürün arasında oluşan bir birliktelik ve satın alan kişinin bir markayı tanımlamasıyla oluşan bir kavramdır.

Marka kişiliği konusunda literatürde farklı modeller bulunmaktadır. Aaker'in beş boyutlu marka kişiliği modeli (1997), arketip modeli (Mark, 2001), ilişki temelli marka kişiliği modeli (Bouslama,2010) bunlardan bazılarıdır. Aaker'ın (1997) oluşturduğu marka kişiliği ölçeği farklı ürün kategorileri ve farklı markalar üzerinde sınanmış ve yapısal geçerlilik açısından doğrulanmıştır, kendinden sonraki marka kişiliği çalışmalarına temel oluşturmuş ve literatürde en çok kullanılan ölçek olarak bilinmektedir (Şahin,2006). Aslen sosyal psikolojide insan kişiliğini ölçen Beş Faktör Modeli'nden faydalanan Aaker, sonuçta ortaya çıan marka kişiliği ölçeğinin de beş boyuttan oluştuğunu, ancak bu ölçeğin yapısal olarak insan kişiliğine benzemediğini ifade etmiştir. 
Aaker (1997) tarafından geliştirilen marka kişiliği ölçeği beş boyut, 15 alt boyut ve 42 maddeden oluşmaktadır. Marka kişiliğinin samimiyet ve heyecan vericilik boyutları; 4 alt boyuttan oluşmakta ve bu boyutlar 11 madde ile ölçümlenmektedir. Yetenek boyutu 3 alt boyut ve bu boyutları ölçen 9 maddeden, seçkinlik boyutu; 2 alt boyut ve bu boyutları ölçen 6 maddeden ve sertlik boyutu; 2 alt boyut ve bu boyutları ölçen 5 maddeden oluşmaktadır Markalardan örnekler vermek gerekirse; Marlboro erkeksi bir yapıya sahipken, Virginia Slims kadınsı bir yapıyı temsil etmektedir. Coca-Cola ile ilişkilendirilen kişilik özellikleri, soğukkanlı, gerçek iken Pepsi ile ilişkilendirilen kişilik özellikleri ise, heyecanlı, genç ve modern olmasıdır (Aaker, 1997: 347-348). Benzer şekillerde, Levi's ve Harley Davidson ile ilişkilendirilen kişilik özelliği dayanıklılık iken; Chanel ile ilişkilendirilen kişilik özelliği kadınsilıktır.

Marka kişiliği oluşturulurken hedef kitlenin ihtiyaçları belirlenmeli ve müşteri ile marka arasında duygusal bir bağ kurulmalıdır. İnsanlar kendine daha yakın hissettiği, kendi kişiliklerine daha yakın gördükleri markaları seçtiği düşünülmektedir (Leblebicioğlu ve Uslu, 2017). Marka kişiliği oluşum aşamasında yardımı olacak üç faktör bulunmaktadır. Aşağıda ilgili faktörler sıralanmıştır (Akdeniz, 2007: 65). Pazardaki Rakip Markalar: Markayı rakiplerden farklılaştırmak marka kişiliğinin temel amaçlarından biridir. Şirketler kendi marka kişiliği için uygun sıfatları oluştururken rakip markaları da düşünmelidir.Sonrasında çeşitli stratejiler uygulaması rakipler karşısında durabilmesi için önemlidir.

Mevcut Markanın Varsa Önceki Kişiliği: Şirketler, markasının mevcutta bir kimliği var ise piyasaya yeni sunduğu ürünü için yeni bir marka adı ile giriş yapmamaktadırlar. Böyle bir durumda yapılacak şeyler arasında markanın pozitif ve negatif noktalarına bakılarak, değiştirilmek istenen özellikler var ise bu noktalar yaratılmak istenen kişilik için referans noktası olarak alınabilir.

Hedef Kitle Özellikleri: Marka kişiliği hedef kitle ile bağlantılıdır; fakat hedef kitle özellikleri dikkate alındığında, marka kişiliğinin hedef kitlenin tüm özelliklerini yansıtması zorunluluğu yoktur. Bazı özellikler müşteri ile uyumlu ya da farklı olabilmektedir. Müşterilerin hayatında ürünlerin nasıl bir yere sahip olacağı düşünülmeli, tüketicinin hangi ihtiyaçlarını karşıladığı belirlenmeli ve kimlik oluşumu bu verilere göre şekillenmelidir.

\section{Tüketici Devam Sütü Satın Alma Tercihine Etki Eden Faktörler}

Tüketicilerin satın alma kararlarına girdi olarak etki eden 3 temel faktör bulunmaktadır. Dış faktörler olarak adlandırılan, bu faktörler, markanın pazarlama çabaları, sosyokültürel çevre ve durumsal etkilerdir (Shiffman ve Kanuk, 2004). Marka yönetimi tarafından yönetilen kararlar olan markaların pazarlama çabaları, ürün, dağıtım, tutundurma ve fiyat ile ilgili kararları içermektedir. Sosyokültürel çevre, kültür, aile, sosyal sınıf, referans gruplarından oluşurken durumsal etkiler, zaman duygusal durum, kolaylaştırıcı etkiler olabilir (Odabaşı ve Barış, 2007).

Tüketici, rasyonel karar verme sürecinde karar verme aşmasına kadar sırasıyla ihtiyacın ortaya çıkması, alternatiflerin belirlenmesi, alternatifler arasından seçim yapılması adımlarından geçer (Mucuk,2004). Bu süreçte girdi olarak yukarıda bahsedilen diş 
faktörlerden ve bu girdilere ek olarak kendi psikolojik ve demografik özelliklerinin de etkisiyle kararını şekillendirir.

Sektörün, ürünün ve hizmetin niteliğine göre değişiklik gösterebilen tüketici tercihinde etkili faktörler bebek devam sütü konu olduğunda; Zhang ve arkadaşları (2015) Çin'de yaptıkları araştırmada devam sütü seçiminde en çok referans gruplarının etkili olduğunu gözlemlemişlerdir. Çocuklu arkadaşların, ailedeki çocuklu akrabaların ve sosyal medyada yer alan, annelere ait yorumların, annelerin devam sütü tercihlerinde en etkili araçlar olduğu görülmektedir. Cui'nin (2016) araştırmasına göre devam sütü markası seçiminde annelerin \% 10 oranında reklamlardan , $\% 7$ oranında internette yer alan bilgilerden, $\% 17$ oranında market görevlilerinin yönlendirmelerinden, \% 15 oranında sağlık personelinin tavsiyelerinden ve \% 29 oranında arkadaş tavsiyesinden etkilendiklerini göstermektedir.

Liu ve arkadaşlarının 2013'de gerçekleştirdikleri çalışma ise devam sütü tercihinde en etkili faktörlerin markaya duyulan güven ve fiyat olduğunu belirtmektedir. Ek olarak aynı çalışma, eğitim ve gelir düzeyi yüksek ailelerin ithal markalardan yana tercihini kullandığını göstermektedir. Cui ise $2016^{\prime}$ da gerçekleştirdiği çalışmasında devam sütü tercihinde etkili faktörleri, fiyat, markaya duyulan güven, ürün menşei (ithal/yerli) ve organik olup olmaması çerçevesinde ele almıştır. Sonuçlar, markaya duyulan güven, fiyat uygunluğu, ürünün organik olması ve ithal marka olmasının her birinin marka tercihinde etkili olduğunu ortaya koymaktadir.

\section{Yöntem}

$\mathrm{Bu}$ araştırmanın amacı annelerin ve pediatristlerin devam sütü seçimlerinde hangi kriterleri ele aldıklarını incelemektir. Bu bağlamda İstanbul'da yaşayan 0-2 yaş annelerinin bebekleri için kullandıkları devam sütü tercihlerinde etkili olan faktörler, öte yandan, pediatristlerin annelere tavsiyede bulunurken dikkate aldığ faktörler belirlenmiş ve her iki grup için tercihe etki eden faktörlerin farklılaşıp farklılaşmadığının tespit edilmiştir. Ek olarak pazar lideri iki devam sütü markasının marka kişiliklerinin anneler ve pediatristler tarafından nasıl algılandığı araştırılmıştır.

Saha çalışması öncesinde anne ve pediatristlerin devam sütü seçiminde tercihlerinin ve karar kriterlerinin neler olduğunu belirlemek amacıyla keşifsel araştırma yöntemlerinden odak grup çalışması gerçekleştirilmiştir. Odak grup çalışması yapılmasının nedeni farklı sosyoekonomik gruplardan annelere ve farklı hastanelerde çalışan hekimlere ulaşarak karşılıklı fikir alışverişinde bulunmalarını ve tecrübelerini paylaşmalarını sağlamaktır. Böylece grubun sinerjik yapısı araştırmacılara daha çeşitli ve daha çok veri toplamada fayda sağlamaktadır. Odak grupların homojenliğinin korunabilmesi için anneler ve hekimler grubu olarak iki ayrı grupla iki farklı oturumda görüşmeler gerçekleştirilmiştir. Odak grup çalışmasından elde edilen bilgilere dayanarak anketteki sorular şekillendirilmiş, devam sütü tercihine etki eden faktörler belirlenmiştir.

Saha araştırmasında anket yöntemi kullanılmış ve araştırma İstanbul'da ikamet eden devam sütü kullanıcısı anneler ve devam sütü tavsiye eden hekimler üzerinde gerçekleştirilmiştir. Anketler anne ve pediatristler için farklı formatlarda hazırlanmıştır. Üç sekmeden oluşan soru formlarının ilk bölümünde anneye/pediatriste ait tanımlayıcı bilgilerin yanı sıra ağırlıklı 
kullandığı/tavsiye ettiği devam sütü markası sorulmuştur. İkinci bölümde, devam sütü seçiminde etkili faktörler ve cevaplayıcının birinci bölümde tercih ettiği markaya ilişkin marka kişiliğine dair sorular sorulmuştur. Raporlama aşamasında marka isimleri doğrudan kullanılmamış onun yerine markalar, takma isimler ile adlandırılmıştır. Son bölümde ise demografik bilgiler toplanmıştır. Anketler sonucunda en çok tercih edilen iki markaya ait veriler istatistiki anlamda analiz edilebilecek miktara ulaştı̆̆ için sadece iki lider markaya ait analizler gerçekleştirilmiştir. Araştırmanın hipotezleri aşağıda sıralanmıştır;

$\mathrm{H}_{1}$ : Appetite ve Happy marka kişilikleri arasında fark vardır.

$\mathrm{H}_{2}$ : Anne ve pediatristlerin marka tercih nedenleri arasında fark vardır.

\section{Evren ve Örneklem}

Araştırmanın ana kütlesini İstanbul ilinde ikamet eden halihazırda 0-2 yaş bebek sahibi olup, devam sütü kullanan anneler ile hastanelerde görev yapan pediatristler oluşturmaktadır. Yapılan pek çok araştırmada zaman ve maliyet kısıtı dolayısıyla ana kütlenin tamamına erişilememekte, ana kütle içinden seçilen örneklem grubu üzerinde araştırma yapılmaktadır. Bu sebepten dolayı araştırmada tesadüfi olmayan örneklem metotlarından biri olan kolayda örneklem metodu kullanılmıştır. İki farklı anket formu üzerinden anne ve pediatristlerin devam sütü tercihi/tavsiyeleri değerlendirmeye alınmıştır. Örneklem, 175 adet devam sütü kullanan anne ve 125 adet devam sütü tavsiye eden pediatristten oluşmaktadır. Anket uygulamasının sınırlı sayıda ve tek ilde yerleşik kişilere ulaştırılmış olmasından dolayı tüm Türkiye'yi genelleyen sonuçlar üretilmesi mümkün olmamıştır.

\section{Veri Toplama Araçları}

Algılanan marka kişiliğini ölçmek için bu alanda geçerliliği kabul edilmiş olan Aaker (1997) tarafından geliştirilmiş samimi, heyecan verici, yeterli, zevk sahibi ve sert olmak üzere beş boyut, on beş alt boyut ve kırk iki özellikten oluşan marka kişiliği ölçeği kullanılmıştır (Tablo 2). Devam sütü tercihinde etkili olan faktörler 5 'li likert tipi ölçeği formatında $5=$ Çok önemli, 4= Önemli, 3= Ne önemli ne önemsiz, 2=Önemsiz, 1= Çok Önemsiz, şeklinde sorulmuştur. Sorular, yapılan literatür taramasında elde edilen bebek beslenmesinde önemli faktörlere ve yapılan odak grup çalışmasının verilerine dayanarak hazırlanmıştır. Ürünün organik olması, ürün çeşidinin fazlalığı, ürünlerin kullanımın kolay ve anlaşılır olması, ürünlerin fiyatı, ambalaj tasarımı, yüksek kalitede olması. vb. değerlendirme kriterlerini içermektedir. 


\begin{tabular}{|c|c|c|c|c|c|}
\hline BOYUTLAR & \begin{tabular}{|l|} 
ALT \\
BOYUTLAR
\end{tabular} & ÖZELLIKLER & BOYUTLAR & \begin{tabular}{|l|} 
ALT \\
BOYUTLAR \\
\end{tabular} & ÖZELLİLER \\
\hline \multirow{11}{*}{ Samimiyet } & \multirow{3}{*}{ Gerçekģi } & Gerçekģi & \multirow{11}{*}{ Coşku } & \multirow{3}{*}{ Cesur } & Cesur \\
\hline & & Aile odakl & & & $\begin{array}{l}\text { Moday1 } \\
\text { izleyen }\end{array}$ \\
\hline & & Taşralı & & & Heyecan verici \\
\hline & \multirow{3}{*}{ Dürüst } & Dürüst & & \multirow{3}{*}{ Esprili } & Esprili \\
\hline & & Samimi (içten) & & & Havali \\
\hline & & Ciddi & & & Genç \\
\hline & \multirow[b]{2}{*}{ Yararli } & Yararl1 & & \multirow[b]{2}{*}{ H ayalperest } & Hayalperest \\
\hline & & $\begin{array}{l}\text { Orijinal } \\
\text { (Özgün) }\end{array}$ & & & Eşsiz \\
\hline & \multirow{3}{*}{ Neşeli } & Neşeli & & \multirow{3}{*}{ Güncel } & Güncel \\
\hline & & \begin{tabular}{|l} 
Duygusal \\
\end{tabular} & & & B ağımsız \\
\hline & & $\begin{array}{l}\text { Arkadaş } \\
\text { canlis1 }\end{array}$ & & & Çağdaş \\
\hline \multirow{9}{*}{ Yeterlilik } & \multirow{3}{*}{ Güvenilir } & Güvenilir & \multirow{6}{*}{ Seçkinlik } & \multirow{3}{*}{ Üst snif } & Üst sinif \\
\hline & & Çalișkan & & & B üyüleyici \\
\hline & & Güvenli & & & İyi görünümlü \\
\hline & \multirow{3}{*}{ Zeki } & Zeki & & \multirow{3}{*}{ Cazibeli } & Cazibeli \\
\hline & & Teknik & & & $\begin{array}{l}\text { Feminen } \\
\text { (K adins })\end{array}$ \\
\hline & & Kurumsal & & & Ş1k \\
\hline & \multirow{3}{*}{ B aşarılı } & B aşaril1 & \multirow{5}{*}{ Dayaniklılik } & \multirow{3}{*}{ Sportif } & Sportif \\
\hline & & Lider & & & $\begin{array}{l}\text { Maskülen } \\
\text { (Erkeksi) }\end{array}$ \\
\hline & & $\begin{array}{l}\text { Kendine } \\
\text { güvenen }\end{array}$ & & & Batili \\
\hline & & & & \multirow[b]{2}{*}{ Sağlam } & \begin{tabular}{|l} 
Sağlam \\
\end{tabular} \\
\hline & & & & & Dayanıkl1 \\
\hline
\end{tabular}

Şekil 1. Aaker'ın Marka Kişiliği Ölçeği

Kaynak: Jennifer L. Aaker, "Dimensions of Brand Personality", Journal of Marketing Research, Vol. 34, August 1997, s.354

\section{Bulgular}

\section{Odak Grup Görüşmelerine Dair Bulgular}

Araştırmanın ilk adımı olarak; hekimlerle hastalarına önerdikleri devam sütü markaları tercihlerini, markadan bağımsız olarak devam sütünden beklentilerini ve devam sütü markalarının zihinlerindeki konumunu ortaya koymak için keşfedici araştırma yöntemlerinden odak grup çalışması yapılmıştır. İki adet odak görüşmesi yapılmış olup, biri 10 adet anneye diğeri ise 10 adet özel veya devlet hastanesi hekiminden oluşan hekimler grubuna uygulanmıştır. Hekimler için devam sütü seçiminde en önemli kriterin ne olduğu sorulduğunda "anne sütüne benzerliği önemli" cevabı alınmıştır. Ancak hekimlerin ifadelerine göre aileler, hekimlerden devam sütü hakkında bilgi almak için geldiklerinde "hangi süt organik?" “en iyi süt organik süt müdür?" "organik süt demek anne sütüne yakın içerikte olması mı demek" şeklindeki sorular yöneltmektedirler.. Ayrıca hekimler, Sağlık Bakanlığı'nın bebek dostu hastane politikası çerçevesinde formül sütler için annelere sadece tavsiye sunduklarını ancak ailenin tercihine müdahale edemediklerini ifade etmişlerdir.

Hekimlere yöneltilen bir diğer soru, hangi devam sütünü önerdikleri olmuştur. Hekimlerin altısı Appetite'yi, üçü Smiley'i ve ikisi Happy'i önerdiklerini ifade etmişlerdir. Pazardaki tüm markalarla ilgili bağımsız çağrışımlar sorulduğunda Appetite markası ile ilgili çağrışımların eski, köklü, güvenilir, sağlıklı olurken, Happy ile ilgili çağrışımlar, ulaşılması en kolay marka, bağışıklık konusunda en güçlü süt, güçlü, güvenilir ve ürün çeşidi fazla olması olmuştur. 
Smiley ile ilgili çağrışımlar ekonomik, güvenilir olarak sıralanırken, Beauty, Eternity ve Sunny markalarına dair güçlü çağrışımlar olmadığı dile getirilmiştir.

Anne grubunda, yine en çok tercih edilen marka 5 kişiyle Appetite, ardından 3 kişiyle Happy ve bir kişi ile Smiley markaları olmuştur. Çağrışımlar sorulduğunda ise Smiley sindirim ile ilgili pozitif çağrışımlara sahipken, Happy ilk olarak organik olması ile akla gelmektedir. Ayrıca, Happy, sosyo-ekonomik durumu yüksek annelerin tercihi olarak görülmektedir. Appetite ise kolay bulunan, güvenilir, pratik kullanımlı kelimeleriyle tanımlanmıştır. Beauty ile ilgili çağrışımlar üç anne ile sınırlı olup, ekonomik, sağlıklı şeklindedir. Anneler grubunun devam sütü seçiminde göz önünde bulundurdukları faktörler sorulduğunda ise alınan cevaplar; "ekonomik olması", "faydalı olması" ve "güvenilir olması"dır.

\section{Anket Çalışmasına Ait Analizler ve Bulgular}

Anket verileri SPSS 22.0 programında analiz edilmiş, frekans tablolarından ve faktör analizinden elde edilen bulgulardan yararlanılarak sonuçlar yorumlanmıştır. Cevaplayıcıların demografik özellikleri ile ilgili sorularda frekans dağılımları ve yüzdeleri raporlanmıştır. Marka kişiliği ile ilgili sorularda önce faktör analizi yapılarak faktörlerin literatüre uygun dağılıp dağılmadığı kontrol edilmiştir. Araştırmada kullanılan ölçeklerin geçerliliğini ölçmek için kullanılan faktör analizi sonucunda her bir faktörün faktör yükleri, öz değerleri ve varyans yüzdeleri dikkate alınmıştır. Sonrasında her bir faktörün güvenilirlik katsayıları incelenmiştir. Güvenilirlik sınırını aşamayan sorular analizden teker teker çıkarılarak faktör analizi yeniden yapılmıştır. Ardından hipotez testleri için bağımsız örneklem T-test testi yapılmış ve fark yaratan grupların ortalamaları incelenmiştir.

Araştırmaya katılan toplam 175 anne katılımcının 86'sının (\%49) 26- 33 yaş aralığında olduğu, 67 kişinin (\%38) 34-41 yaş aralığında olduğu, 42-50 yaş aralığında ise sadece 6 annenin araştırmaya katkı sağladığı görülmüştür. Annelerin gelir gruplarının ağırlıklı olarak 64 kişi ile 3001-5000 skalasında, 56 kişi ile de 5001-8000 skalasında olduğu görülmektedir. Toplamda 175 kişilik anne grubunun \%70'i yükseköğrenim görmüş annelerden oluşup, \%17'si de ortaokul mezunu annelerden oluşmaktadır. Lisansüstü öğrenim görmüş anne sayısı ise 23 kişidir (\%13). Annelerin bebeklerinin yaş dağılımı incelenecek olursa, 91'inin (\%52) 0-1 yaş arasında bebeğe sahip olduğu, diğerlerinin de 72'sinin (\%41) 1-2 yaş aralığında ve 12'sinin de (\%7) 2 yaş ve üstü bebeğe sahip olduğu görülmektedir. Annelerin \%57'si özel sektör çalışanıdır. (Tablo 1a). 
Tablo 1a. Anne Grubuna Ait Demografik Veriler

\begin{tabular}{|c|c|c|c|}
\hline \multicolumn{2}{|c|}{ Anne Grubu } & \multirow{2}{*}{$\begin{array}{l}\mathbf{N} \\
175\end{array}$} & \multirow{2}{*}{$\begin{array}{l}\% \\
100 \\
\end{array}$} \\
\hline Toplam & & & \\
\hline \multirow[t]{5}{*}{ Yaş } & $18-25$ & 16 & 10 \\
\hline & $26-33$ & 86 & 49 \\
\hline & $34-41$ & 67 & 38 \\
\hline & $42-50$ & 6 & 3 \\
\hline & 50 üstü & 0 & 0 \\
\hline \multirow[t]{6}{*}{ Gelir (TL) } & 3000 alt 1 & 27 & 15 \\
\hline & $3001-5000$ & 64 & 37 \\
\hline & $5001-8000$ & 56 & 32 \\
\hline & $8001-10,000$ & 21 & 12 \\
\hline & $10001-15,000$ & 7 & 4 \\
\hline & 15.000 üstü & - & - \\
\hline \multirow[t]{4}{*}{ Öğrenim Durumu } & İlköğretim & - & - \\
\hline & Ortaöğretim & 30 & 17 \\
\hline & Yüksek Öğretim & 122 & 70 \\
\hline & Yüksek Lisans /Doktora & 23 & 13 \\
\hline \multirow[t]{3}{*}{ Bebek Yaşı } & 0-1 Yaş arası & 91 & 52 \\
\hline & 1-2 Yaş arası & 72 & 41 \\
\hline & 2 Yaş ve üstü & 12 & 7 \\
\hline \multirow[t]{4}{*}{ Meslek } & Ev Hanımı & 26 & 15 \\
\hline & Devlet Memuru & 19 & 11 \\
\hline & Serbest meslek & 30 & 17 \\
\hline & Özel sektör çalışanı & 100 & 57 \\
\hline
\end{tabular}

Araştırmaya katılan toplam 125 pediatrist katılımcının, 55'i kadın (\%44), 70'i erkek (\%56) olup, yaş dağılımları 55 kişi ile \%44'lük bir oranda 26-33 yaş aralığında toplanmıştır. 26-33 yaş aralığını sırasıyla; 36 kişi ile 34-41 yaş aralığ (\%28) ve 29 kişi ile de $42-50$ yaş aralığı (\%25) takip etmektedir. Katılımcılardan sadece 5 kişi, 50 yaş ve üstü olup, genel olarak araştırmanın örneklem grubunu genç pediatristlerin oluşturduğu gözlemlenmektedir. Pediatristlerin gelir grubu ağırlıklı olarak 53 kişi ile (\%42) 8.001-10.000 TL skalasında toplanmakta, çalıştıkları kurum yapısına bakıldı̆̆ında ise, araştırmaya katılan pediatristlerin \%53'ü özel sektör, \% 47'si devlet çalışanıdır. Toplam 125 pediatristin 73'ünün (\%59) 0-2 yıl arası deneyime sahip olduğu, 21 'inin (\%15) ise 7-15 yıl arasında deneyim sahibi olduğu görülmektedir. 16 yıl ve üstü tecrübeli pediatristlerin ise genel katılımcılar içindeki oranı 19 kişi ile \%11'dir (Tablo 1b). 
Tablo 1b. Pediatrist Grubuna Ait Demografik Veriler

\begin{tabular}{llll}
\hline \multicolumn{2}{c}{ Pediatrist Grubu } & N & \% \\
\hline Toplam & & 125 & 100 \\
\hline Cinsiyet & Kadın & 55 & 44 \\
Yaş & Erkek & 70 & 56 \\
& $26-33$ & 55 & 44 \\
& $34-41$ & 36 & 28 \\
Gelir (TL) & $42-50$ & 29 & 25 \\
& 50 üstü & 5 & 3 \\
& $3001-5000$ & 6 & 5 \\
& $5001-8000$ & 46 & 37 \\
Çalıştığ1 Kurum & $8001-10.000$ & 53 & 42 \\
& $10001-15.000$ & 17 & 14 \\
Çalışma Süresi & 15.000 üstü & 3 & 2 \\
& Özel & 66 & 53 \\
& Devlet & 59 & 47 \\
& 3-6 yıl & 73 & 59 \\
& $7-15$ yıl & 12 & 7 \\
& 16 ve üstü yıl & 19 & 15 \\
& & & 11 \\
\hline
\end{tabular}

Toplam 175 anne anketinin sonuçlarına göre annelerin birinci devam sütü tercihi 95 kişi ile \%54,29'luk bir oranda Appetite markası olarak raporlanmaktayken, 65 kişilik bir anne grubunun $(\% 37,14)$ birinci marka tercihi ise Happy markası olmuştur. Pediatristlerin birinci önerdiği marka anneler grubunda olduğu gibi, Appetite markası olurken (100 kişi, \%80), pediatristlerdan 20 kişi ise (\%16) ilk marka tercihinde Beauty'i da önerdiklerini, diğer 5 kişi de Happy markasını (\%4) önerdiklerini belirtmişlerdir

Marka kişiliği ölçümü en çok tercih edilen ve pazarda en çok paya sahip olan Appetite ve Happy markaları için yapılmıştır. IMS verilerine göre Appetite markası 2016 yılında \%55 gibi bir pazar payına sahip iken 2017 yılı 10 ayda \%50 Pazar payına gerilemiştir. Happy ise 2016 yılında \%5 olan Pazar payını 2017 yılı 10 ayda \%9 a çıkarmıştır (2017 IMS verisi). Marka kişiliği ölçekleri Varimax metoduyla faktör analizine tabi tutulmuş ve marka kişiliği içerisindeki alt boyutlar belirlenmiştir. Faktör yükleri 0,50' nin altında kalan değişkenler analiz dışı bırakılmıştır (Durmuş vd., 2013). Orijinal ölçekteki beş boyutlu dağılımdan farklı olarak, Appetite verisi 10 boyut olarak, Happy verisi ise 6 boyuttan oluşmuştur. Faktör analizi sonucunda ortaya çıkan tüm alt faktörlerin Cronbach alpha güvenilirlik katsayısı kritik değer olan 0,70'in üstünde bulunmuştur (Durmuş vd., 2013). Faktörlerin dağılımlarına ait tablolar Ek1 ve Ek 2' de sunulmuştur.

Appetite marka kişiliğini ortaya koyan on faktör marka kişiliğinin \%70,93'ünü açılamaktadır. Modelin Kaiser Mayer Olkin (KMO) yeterlilik ölçüsü 0.766 bulunmuştur. KMO değerinin 
\%50'den büyük olması değişkenlerin faktör analizine uygun olduğunu göstermektedir (Durmuş vd, 2013:80). Bartlett testinde anlamlılık değerinin 0.05 kritik değerinden küçük olması faktör analizinin \%95 güvenilirlikle anlamlı olduğunu ifade etmektedir (Durmuş vd, 2013:79). Bartlett testi sonucu $p=0.00$ olması faktör analizi sonuçlarının anlamlı olduğunu göstermektedir. Seçkinlik başlığı altında toplanan iyi görünümlü, büyüleyici, cazibeli ve genç özellikleri Appetite markasının en ön planda olan marka kişilik özellikleridir. İkinci faktör olan Samimiyet, toplam varyansın \%7,62'sini açılamakta olup; yararlı, ciddi, orijinal ve samimi marka kişiliği özelliklerini yansıtmaktadır. Üçüncü boyutolan Sertlik, varyansın \%6,91'ni açıklamakta ve sağlam, dayanıklı ve batılı sıfatlarından oluşmaktadır. Dördüncü boyut olan Neşeli, varyansın, \%6,66'sını; neşeli, duygusal ve arkadaş canlısı özellikleriyle ifade ederken, beşinci boyut olan Cesur, varyansın \%4,98'lik kısmını moda, heyecan verici ve cesur sıfatlarıyla açıklamaktadır. Altıncı faktör olan Cazibeli, toplam varyansın \%4,71'ini feminen, şık ve sportif sıfatlarıyla açıklarken; yedinci faktör olan Zeki, varyansın \%4,49'unu teknik, kurumsal ve zeki özellikleriyle açıklamaktadır. Diğer faktörler sırasıyla Güvenilir, Başarılı ve Coşkulu başlıklarının altında toplanmış olup, sırasıyla varyansın \%4,02, \%3,78 ve \%3,75'ini açiklamaktadır.

Happy marka kişiliği için yapılan faktör analizleri sonucu elde edilen 6 faktör marka kişiliğinin \%84,18'ini açıklamaktadır. Kaiser Mayer Olkin (KMO) yeterlilik ölçüsü 0.861 bulunmuştur. Bartlett testi sonucunun ise $p=0.00$ olması faktör analizi sonuçlarının anlamlı olduğunu göstermektedir. Birinci faktör, toplam varyansın \%27,24'ünü açılamaktadır. Samimiyet başlı̆̆ı altında toplanan samimi, dürüst, hayalperest, arkadaş canlısı, duygusal, heyecan verici, neşeli ve taşralı özellikleri Happy markasının en öne çıkan marka kişilik özellikleridir. İkinci faktör olan Cazibeli, toplam varyansın \%21,28'ini açıklamakta olup; bağımsız, dayanıklı, çağdaş, sportif, feminen, genç, şık marka kişiliği özelliklerini yansıtmaktadır. Üçüncü boyut olan Yeterlilik, varyansın \%11,21'ini açılamakta ve üst sınıf, lider, başarılı, zeki, aileci ve kendine güvenen sıfatlarından oluşmaktadır. Dördüncü boyut olan Güvenilir, varyansın, \%10,42' sini batıll, kurumsal, çalışkan, güvenli özellikleriyle ifade ederken; beşinci boyut olan Yararlı, varyansın \%8,6'sını yararlı, orijinal, güncel sıfatlarıyla açıklamaktadır. Altıncı ve son faktör olan Seçkinlik, toplam varyansın \%5,4'ünü iyi görünümlü ve havalı başlıklarının altında toplanmıştır.

H1: Appetite ve Happy'nin marka kişilikleri arasında fark vardır.

$\mathrm{H}_{1}$ hipotezini test etmek için Appetite ve Happy marka kişilikleri arsında fark olup olmadığını test etmek için 42 'şer alt değişkenin her birine bağımsız t-test analizi uygulanmıştır. Tablo 2' de görüldüğü üzere $\mathrm{T}$ testi sonuçlarına göre, her iki markanın marka kişiliği karşılaştırmasında, markanın gerçekçi, aile odaklı, dürüst, samimi, yararlı, orijinal, neşeli, duygusal, arkadaş canlısı, cesur, modayı izleyen, heyecan verici, esprili, havalı, hayalperest, bağımsız, çalışkan, teknik, başarılı, lider, kendine güvenen, büyüleyici, iyi görünümlü, cazibeli, kadınsı, şık, sportif, sağlam, dayanıklı olması kişilik özellikleri açısından fark olduğu istatistiki olarak kabul edilmektedir $(\mathrm{p}<0,05)$. Tablo 3 'de $\mathrm{T}$ testi değişken ortalamaları karşılaştırıldığında, Appetite markasının Happy markasına kıyasla daha gerçekçi, aile dostu, dürüst, samimi yararlı, orijinal, neşeli, duygusal, arkadaş canlısı, cesur, modayı takip eden, heyecan verici, esprili, havalı, hayalperest, bağımsız, çalışkan, teknik, başarılı, lider, kendine güvenen, büyüleyici, iyi görünümlü, cazibeli, şık, sportif, sağlam ve dayanıklı olduğu ortaya 
çıkmaktadır. Yalnızca Happy markası, Appetite markasına göre daha feminen olarak algilanmaktadır.

Tablo 2. Appetite ve Happy Marka Kişilikleri T Testi Sonuçları

\begin{tabular}{|c|c|c|c|c|}
\hline Marka Kişiliği & $\mathbf{t}$ & Df & Sig. (2-tailed) & $\mathbf{H}_{1}$ \\
\hline Gerçekçi & 4,215 & 96,172 & 0,00 & Kabul \\
\hline Aile odaklı & 5,521 & 96,013 & 0,00 & Kabul \\
\hline Taşralı & $-0,496$ & 95,387 & 0,621 & Red \\
\hline Dürüst & 2,712 & 76,821 & 0,008 & Kabul \\
\hline Samimi & 3,284 & 88,456 & 0,001 & Kabul \\
\hline Ciddi & 1,605 & 98 & 0,112 & Red \\
\hline Yararl1 & 0,025 & 0,025 & 0,025 & Kabul \\
\hline Orjinal & 2,687 & 98 & 0,008 & Kabul \\
\hline Neşeli & 4,659 & 97,537 & 0,00 & Kabul \\
\hline Duygusal & 2,178 & 96,212 & 0,032 & Kabul \\
\hline Arkadaş canlısı & 4,354 & 93,335 & 0,00 & Kabul \\
\hline Cesur & 2,187 & 90,994 & 0,031 & Kabul \\
\hline Modayı izleyen & 5,108 & 75,874 & 0,00 & Kabul \\
\hline Heyecan verici & 5,835 & 90,373 & 0,00 & Kabul \\
\hline Espirili & 5,838 & 93,032 & 0,00 & Kabul \\
\hline Havalı & 3,616 & 88,217 & 0,00 & Kabul \\
\hline Genç & 1,351 & 98 & 0,18 & Red \\
\hline Hayalperest & 4,284 & 98 & 0,00 & Kabul \\
\hline Eşsiz & $-1,834$ & 97,91 & 0,07 & Red \\
\hline Güncel & $-0,871$ & 98 & 0,386 & Red \\
\hline Bağımsız & 2,152 & 85,281 & 0,034 & Kabul \\
\hline Çağdaş & 0,394 & 98 & 0,695 & Red \\
\hline Güvenilir & $-0,139$ & 98 & 0,89 & Red \\
\hline Çalışkan & 2,129 & 98 & 0,036 & Kabul \\
\hline Güvenli & $-0,636$ & 98 & 0,526 & Red \\
\hline Zeki & 0,769 & 92,469 & 0,444 & Red \\
\hline Teknik & 2,475 & 98 & 0,015 & Kabul \\
\hline Kurumsal & 0,25 & 98 & 0,803 & Red \\
\hline Başarılı & 2,487 & 94,242 & 0,015 & Kabul \\
\hline Lider & 2,239 & 84,594 & 0,028 & Kabul \\
\hline Kendine güvenen & 3,032 & 98 & 0,003 & Kabul \\
\hline Üst sinıf & 1,516 & 84,112 & 0,133 & Red \\
\hline Büyüleyici & 4,065 & 98 & 0,00 & Kabul \\
\hline İyi görünümlü & 2,529 & 98 & 0,013 & Kabul \\
\hline Cazibeli & 6,194 & 98 & 0,00 & Kabul \\
\hline Kadınsı & $-2,131$ & 93,253 & 0,036 & Kabul \\
\hline Şık & 4,557 & 89,814 & 0,00 & Kabul \\
\hline Sportif & 4,656 & 82,074 & 0,00 & Kabul \\
\hline Maskülen & 1,202 & 98 & 0,232 & Red \\
\hline Batılı & 0,584 & 94,547 & 0,56 & Red \\
\hline Sağlam & 2,06 & 98 & 0,042 & Kabul \\
\hline Dayanıklı & 2,406 & 94,171 & 0,018 & Kabul \\
\hline
\end{tabular}

Tablo 3. Appetite ve Happy Marka Kişiliği T Testi Grup Ortalamaları 


\begin{tabular}{|c|c|c|c|c|c|}
\hline Kişilik & Marka & $\mathrm{N}$ & Ortalama & $\begin{array}{c}\text { Std. } \\
\text { Sapma }\end{array}$ & $\begin{array}{c}\text { Std. } \\
\text { Hata Ort }\end{array}$ \\
\hline \multirow[t]{2}{*}{ Gerçekçi } & Appetite & 48 & 44,375 & 0,50133 & 0,07236 \\
\hline & Happy & 52 & 39,615 & 0,62502 & 0,08667 \\
\hline \multirow[t]{2}{*}{ Aile } & Appetite & 48 & 45,833 & 0,49822 & 0,07191 \\
\hline & Happy & 52 & 39,615 & 0,62502 & 0,08667 \\
\hline \multirow[t]{2}{*}{ Dürüst } & Appetite & 48 & 43,542 & 0,5255 & 0,07585 \\
\hline & Happy & 52 & 41,154 & 0,3226 & 0,04474 \\
\hline \multirow[t]{2}{*}{ Samimi } & Appetite & 48 & 4,375 & 0,56962 & 0,08222 \\
\hline & Happy & 52 & 40,385 & 0,4411 & 0,06117 \\
\hline \multirow[t]{2}{*}{ Yararlı } & Appetite & 48 & 43,958 & 0,64378 & 0,09292 \\
\hline & Happy & 52 & 41,154 & 0,58255 & 0,08079 \\
\hline \multirow[t]{2}{*}{ Orjinal } & Appetite & 48 & 44,583 & 0,54415 & 0,07854 \\
\hline & Happy & 52 & 40,962 & 0,77357 & 0,10728 \\
\hline \multirow[t]{2}{*}{ Neşeli } & Appetite & 48 & 41,667 & 0,83369 & 0,12033 \\
\hline & Happy & 52 & 33,846 & 0,84375 & 0,11701 \\
\hline \multirow[t]{2}{*}{ Duygusal } & Appetite & 48 & 40,625 & 0,7553 & 0,10902 \\
\hline & Happy & 52 & 36,923 & 0,94014 & 0,13037 \\
\hline \multirow{2}{*}{ Arkadaş } & Appetite & 48 & 4,125 & 0,78889 & 0,11387 \\
\hline & Нарру & 52 & 33,077 & 107,628 & 0,14925 \\
\hline \multirow[t]{2}{*}{ Cesur } & Appetite & 48 & 40,417 & 0,82406 & 0,11894 \\
\hline & Happy & 52 & 35,962 & 119,245 & 0,16536 \\
\hline \multirow[t]{2}{*}{ Moda } & Appetite & 48 & 43,125 & 0,6242 & 0,0901 \\
\hline & Happy & 52 & 33,077 & 126,085 & 0,17485 \\
\hline \multirow[t]{2}{*}{ Heyecan verici } & Appetite & 48 & 41,875 & 0,84189 & 0,12152 \\
\hline & Happy & 52 & 29,615 & 123,608 & 0,17141 \\
\hline \multirow[t]{2}{*}{ Espirili } & Appetite & 48 & 42,708 & 0,86884 & 0,12541 \\
\hline & Happy & 52 & 30,577 & 119,498 & 0,16571 \\
\hline \multirow[t]{2}{*}{ Havalı } & Appetite & 48 & 42,708 & 0,76463 & 0,11037 \\
\hline & Happy & 52 & 35,577 & 117,846 & 0,16342 \\
\hline \multirow[t]{2}{*}{ Hayalperest } & Appetite & 48 & 38,542 & 0,89893 & 0,12975 \\
\hline & Happy & 52 & 29,423 & 119,498 & 0,16571 \\
\hline \multirow[t]{2}{*}{ Bağımsız } & Appetite & 48 & 42,292 & 0,62704 & 0,0905 \\
\hline & Happy & 52 & 38,654 & 102,954 & 0,14277 \\
\hline \multirow[t]{2}{*}{ Çalışkan } & Appetite & 48 & 44,792 & 0,54537 & 0,07872 \\
\hline & Happy & 52 & 42,115 & 0,69555 & 0,09646 \\
\hline Teknik & Appetite & 48 & 42,917 & 0,61742 & 0,08912 \\
\hline & Нарру & 52 & 39,423 & 0,77746 & 0,10781 \\
\hline Başarılı & Appetite & 48 & 45,833 & 0,53924 & 0,07783 \\
\hline & Happy & 52 & 42,692 & 0,71717 & 0,09945 \\
\hline Lider & Appetite & 48 & 46,042 & 0,64378 & 0,09292 \\
\hline & Happy & 52 & 42,115 & 107,259 & 0,14874 \\
\hline Kendine güvenen & Appetite & 48 & 45,208 & 0,65199 & 0,09411 \\
\hline & Нарру & 52 & 40,192 & 0,95979 & 0,1331 \\
\hline Büyüleyici & Appetite & 48 & 41,667 & 0,80776 & 0,11659 \\
\hline & Happy & 52 & 34,615 & 0,9174 & 0,12722 \\
\hline İyi görünümlü & Appetite & 48 & 43,333 & 0,63021 & 0,09096 \\
\hline & Happy & 52 & 39,231 & 0,94653 & 0,13126 \\
\hline Cazibeli & Appetite & 48 & 44,375 & 0,64926 & 0,09371 \\
\hline & Happy & 52 & 36,731 & 0,58481 & 0,0811 \\
\hline Feminen & Appetite & 48 & 30,417 & 0,71335 & 0,10296 \\
\hline & Hарру & 52 & 34,038 & 0,97538 & 0,13526 \\
\hline Şık & Appetite & 48 & 42,083 & 0,61742 & 0,08912 \\
\hline & Happy & 52 & 35,000 & 0,91823 & 0,12733 \\
\hline Sportif & Appetite & 48 & 41,667 & 0,75324 & 0,10872 \\
\hline & Happy & 52 & 31,731 & 13,243 & 0,18365 \\
\hline Sağlam & Appetite & 48 & 46,042 & 0,57388 & 0,08283 \\
\hline & Happy & 52 & 43,846 & 0,49125 & 0,06812 \\
\hline Dayanıklı & Appetite & 48 & 44,375 & 0,58003 & 0,08372 \\
\hline & Happy & 52 & 41,731 & 0,5134 & 0,0712 \\
\hline
\end{tabular}

$\mathrm{H}_{2}$ : Anne ve pediatristlerin marka tercih-öneri nedenleri arasında fark vardır.

$\mathrm{H}_{2}$ hipotezini test etmek için marka tercihine ait önceden belirlenen 18 değişken anne ve pediatristler tarafından 5'li likert ölçekle önem derecesine göre puanlandırılmıştır. Ardından anne ve pediatrist gruplarına bağımsız T-test analizi uygulanarak, anne ve pediatristlerin devam sütü tercihi/önerisinde bir fark olup olmadığ 0.05 anlamlılık düzeyinde test edilmiştir. Tablo 4 ' de $\mathrm{H}_{2}$ hipotezine ait tablo değerleri sunulmuştur.

Tablo 4 incelendiğinde, marka tercihinde etkili olan değişkenlerden ürünün organik olması, ürün çeşidi, kullanımı kolay olması, ürün fiyatı, ürün ambalajı, markanın yenilikçi bir marka olması, çeşitliliği, anne sütüne yakın olması, markanın dikkat çekici reklamlarının olması, satış 
sonrası memnuniyeti, indirimleri olması ve bir danışma hattının olması değişkenlerinin istatistiki olarak anlamlı olduğu görülmektedir $(p<0,05)$. Dolayısıyla bu değişkenlerin anne ve pediatristler arasında fark gösterdiği kabul olmuş, diğerleri ise reddedilmiştir. ( $p>0,05)$

T-testi değişken ortalamaları incelendiğinde, anneler pediatristlere oranla; ürünün organik olması, markanın dikkat çekici reklamlarının olması, markanın satın alma sonrası memnuniyetinin yüksek olması, markanın fazla sayıda indirim kampanyası olması ve bir danışma hattının olması değişkenlerine daha fazla önem verirken pediatristlerin ise annelere nazaran, marka tercih nedenlerinde ürün çeşitliliği, ürünün kullanımının kolay olması, ürünün fiyatı, ürünün ambalajı, ürünün yenilikçi bir marka olması, farklı çeşitler bulundurması, anne sütüne olan yatkınlı̆̆ gibi konulara daha fazla önem verdiği ortaya çıkmaktadır.

Tablo 4. Anne ve Pediatristlerin Marka Tercih/Öneri Nedenleri Bağımsız T-Testi Sonuçları

\begin{tabular}{lllll}
\hline Marka Tercih Nedenleri & \multicolumn{1}{c}{$\mathbf{t}$} & $\mathbf{d f}$ & Sig. & $\mathbf{H}_{\mathbf{2}}$ \\
\hline Organik & $-5,303$ & 287,291 & 0,00 & Kabul \\
Ürün çeşidi & 5,608 & 289,384 & 0,00 & Kabul \\
Kullanımı kolay & 1,992 & 273,211 & 0,047 & Kabul \\
Ürün fiyatı & 9,613 & 297,759 & 0,00 & Kabul \\
Ürün ambalaj & 4,718 & 256,939 & 0,00 & Kabul \\
Ürün kalite & 0,06 & 298 & 0,952 & Red \\
Ürün uzun sure pazar & $-0,072$ & 298 & 0,943 & Red \\
Markaya güven & $-1,875$ & 261,581 & 0,062 & Red \\
Yenilikçi marka & 2,461 & 289,996 & 0,014 & Kabul \\
Bilinir marka & 0,116 & 270,781 & 0,908 & Red \\
Marka çeşit & 4,63 & 291,645 & 0,00 & Kabul \\
Anne sütüne benzerlik & $-2,419$ & 282,621 & 0,016 & Kabul \\
Marka reklam & $-2,419$ & 282,621 & 0,016 & Kabul \\
Memnuniyet & $-6,536$ & 247,726 & 0,00 & Kabul \\
Bulunabilirlik & $-0,038$ & 279,853 & 0,97 & Red \\
Marka indirimleri & $-2,06$ & 291,119 & 0,04 & Kabul \\
Marka danışma hattı & $-5,962$ & 279,048 & 0,00 & Kabul \\
Marka prestiji & $-0,903$ & 263,6 & 0,367 & Red \\
\hline
\end{tabular}

\section{Tartışma, Sonuç ve Öneriler}

Bu çalışmada, 0-2 yaş annelerinin ve pediatristlerin devam sütü tercihleri sorgulanmış; kullanıcıların tercih/tavsiye ettiği markaya ilişkin marka kişiliği algıları ölçülmüş ve pazarda en çok tercih edilen markaların marka kişiliği unsurları arasında fark olup olmadığına bakılmıştır. Yanı sıra, devam sütü markası seçerken dikkate alınan hususlar incelenmiş anne ve çocuk pediatristlerinin tercihleri arasında farklılık olup olmadığı ortaya konmuştur.

Toplam 175 anne üzerinde uygulanan anketinin sonuçlarına göre annelerin devam sütünde ilk tercihi 95 kişi ile $(\% 54,2)$ Appetite markası iken 65 kişi ile $(\% 37,14)$ Happy markası olmuştur. Pediatristlerin \% 80'inin ilk sırada önerdiği marka, anneler grubunda da olduğu gibi Appetite markası olurken \%16'sının ilk marka tercihi Beauty, kalan \% 4'ün de Happy markası olmuştur. Bu durumun olası açıklaması, Appetite'in marka çalışmalarında 
ürünün doğal ve anne sütüne yakınlığını vurgulaması, Happy'nin son zamanlarda popülarite kazanan "organik" kelimesine odaklanarak ürünün organik olduğunu vurgulamasıdır. Pediatristler grubu, anne sütüne en yakın devam sütünü tercih etmek isterken, anneler ise konunun güncelliği nedeniyle organik ürünleri tercih edebilmektedirler. Ancak burada dikkate dilmesi gereken nokta ürünün organik olması, anne sütüne yakın olduğu anlamına gelmemektedir. "Organik olan sağlıklıdır" algısının oluşması, bebeklerine en iyisini vermeye çalışan annelerin organik ürünü seçme çabasını doğurmaktadır.

Appetite ve Happy markalarına ilişkin marka kişiliği analizi sonuçlarına göre; Appetite markasının seçkinlik başlı̆̆ı altında toplanan, iyi görünümlü, büyüleyici, cazibeli ve genç özellikleri en ön planda olan marka kişilik özellikleridir. İkinci faktör olarak belirlenen samimiyet, yararlı, ciddi, orijinal ve samimi marka kişiliği özelliklerini yansıtmaktadır. Üçüncü boyut olan sertlik, sağlam, dayanıklı ve batılı sıfatlarından oluşmaktadır. Appetite markası, hem anneler hem de pediatristlerin yer aldığı örneklem grubu için seçkin, yararlı, ithal marka olarak tanımlanmaktadır. Elde edilen bulgular, Cui'nin (2016) çalışmasıyla büyük oranda örtüşmektedir. Cui (2016) çalışmasında annelerin devam sütü marka tercihlerinde ürün menşeinin ithal olmasının önemini vurgulamıştır.

Happy markası için ise Samimiyet başlığı altında toplanan samimi, dürüst, hayalperest, arkadaş canlısı, duygusal, heyecan verici, neşeli ve taşralı özellikleri en öne çıkan marka kişilik özellikleridir. İkinci faktör olan Cazibeli, bağımsız, dayanıklı, çağdaş, sportif, feminen, genç, şık marka kişiliği özelliklerini yansıtmaktadır. Özetle anne ve pediatristlerdan oluşan cevaplayıcılar, Happy markasını, eğlenceli, güvenilir, dayanıklı ve genç bir marka olarak tanımlamaktadır. Yine Cui'nin (2016) çalışmasında, annelerin devam sütü marka tercihlerinde markaya duyulan güvenin en önemli etmenlerden biri olduğu gözlemlenmiştir.

Çalışmanın sonucunda marka kişiliği unsurlarının bir tanesi hariç diğer tümün de (gerçekçi, aile dostu, dürüst, samimi yararlı, orijinal, neşeli, duygusal, arkadaş canlısı, cesur, modayı takip eden, heyecan verici, esprili, havalı, hayalperest, bağımsız, çalışkan, teknik, başarılı, lider, kendine güvenen, büyüleyici, iyi görünümlü, cazibeli, şık, sportif, sağlam ve dayanıklı) Appetite markasının Happy markasına kiyasla daha fazla puan aldığı görülmüştür. Happy markasının, Appetite markasına göre sadece daha feminen olarak algılandığı gözlenmiştir. Bunun olası sebepleri Appetite markasının pazardaki yaşam süresinin Happy markasına göre çok daha uzun olması, Pazar payının ve bilinirliğinin daha yüksek olmasıdır. Happy markasının marka iletişim çalışmaları markayı daha feminen özellikleri ile ön plana çıkararak bu noktada Appetite'den farklılaştırmıştır.

Anne ve pediatristlerin marka tercih nedenlerinde ne derece farklılaştığını gösteren analiz sonucunda, anneler pediatristlere oranla ürünün organik olması, markanın dikkat çekici reklamlarının olması, markanın satın alma sonrası memnuniyetinin yüksek olması, markanın fazla sayıda indirim kampanyası olması ve bir danışma hattının olması değişkenlerine daha fazla önem verirken, pediatristlerin annelere nazaran; marka tercih nedenlerinde ürün çeşitliliği, ürünün kullanımının kolay olması, ürünün fiyatı, ürünün ambalajı, ürünün yenilikçi bir marka olması, farklı çeşitler bulundurması, anne sütüne olan yatkınlı̆̆ı gibi konulara daha fazla önem verdiğ gözlenmiştir. Liu ve arkadaşlarının çalışması (2013), annelerin seçimlerinde etkili faktörlerin birinin de fiyat olduğu sonucunu desteklemektedir. Cui'nin (2016) araştırması ise annelerin 
reklamlardan \% 10 oranında etkilendiğini ortaya koyarak, araştırma bulgularını destekler niteliktedir.

Pediatristlerin deneyim yılı göz önüne alındığında marka tercih nedenleri arasında belirgin farklar bulunmamaktadır. Bunun sebebi pediatristlerin asistanlık zamanın da bebek beslenmesi ile ilgili bir eğitim almamaları ve zamanla konu hakkında tecrübe edinmeleri olabilir. Genel olarak pediatristlerin bebek beslenmesinde, anne sütüne en yakın devam sütü seçmeye yatkın oldukları görülmektedir.

Çalışmanın başlıca kısıtı, örneklem sayısının yeterince büyük olmaması ve İstanbul ilinde ikamet eden annelerle sınırlı olmasıdır. Dolayısıyla tüm Türkiye'yi genelleyen sonuçlar üretmek mümkün değildir.

Çalışma sonucu elde edilen bulguların, hem literatüre hem de marka yöneticilerine ürünlerini konumlandırma çalışmalarında ön görü sağlayacağına inanılmaktadır. Baskın marka kişiliklerinin ön plana çıkarılmasıyla rekabetçi pazarda ürünü tutundurma faaliyetlerinde etkin bir araç olarak kullanılması, marka yönetimleri için rekabet avantajı sağlamaktadır. Bunun yanı sıra İstanbul ili için kullanıcı profillerinin belirlenmesinde, hedef kitlenin tanınması ve dolasıyla doğru iletişim kurulmasında yardımcı olacaktır.

Spesifik olarak Appetite'in Happy ile daha yoğun rekabet edebilmesi için annelere odaklanması ve organiklik kavramı ile doğallık kavramının farklarını iyi anlatması gerekmektedir. Pediatristler için anne sütüne yakınlık daha önemli bir kriterken annelerin "organik" sözcüğünden daha çok etkilendiği görülmektedir. Organik, kelime anlamıla "doğal yolla yapılan" anlamı ifade etmektedir (TDK,2017). Ancak, organik süt demek anne sütüne yakın demek değildir. Bazı organik bebek sütleri nişasta içermektedir ancak anne sütünde nişasta bulunmaz. Anne sütünün karbonhidrat kaynağ1 nişasta değil laktozdur. Devam sütünün anne sütüne yakın olması için önemli kriterler, anne sütünde bulunan Omega 3, prebiyotik ve nükleotidleri içermesidir (Uzmantv, erişim 14.02.2018)

Happy'nin ise Appetite ile rekabet edebilmesi için ürün çeşitliliğini, kullanım kolaylığını ve yenilikçilik yönünü arttırması gerekmektedir. Appetite markasının dayanıklılık ve teknik kişilik özelliklerinde Happy'e göre daha yüksek puan alması, akıllı kutu tasarımlarından kaynaklandığını düşündürmektedir. Appetite markasının kilitli kapak sitemi olması, içerisinde ölçüyü ayarlamak için bir kesik noktası olması kullanıcılara kolaylık sağlamakta ve yenilikçi yönünü ön plana çıkarmaktadır. Happy markası ise daha geleneksel tipte plastik kapaklı, ölçü kesiği olmayan bir ambalaj kullanmaktadır.

Appetite markası pazarda pek çok farklı ürünle yer almaktadır. Özel ihtiyaç durumlarında daha fazla alternatif sunabilmektedir. Happy markasının fiyat olarak Appetite'nin biraz daha üzerinde olması bazı kullanıcılar için daha kaliteli olduğu algısı yaratmaktayken, daha fiyat odaklı kullanıcılar için dezavantaj olabilmektedir. Bu sebeple Happy markası dağıtım ağını daha seçkin marketler ve eczaneler ile sınırlı tutmalıdır. Appetite markasının ucuzluk marketleri de dahil olmak üzere, pek çok zincir marketlerde ve eczanelerde kolayca bulunduğu görülmektedir. 


\section{Kaynakça}

Aaker, D. (1991). Managing Brand Equity. Capitalizing on The value of a Brand name. The Free Press, New York

Aaker, J.L. (1997). Dimensions of Brand Personality. Journal of Marketing Research, 34 (3), 347356.

Aaker J.L, Benet-Martinez M, Garolera J. (2001) Consumption Symbols as Carries of Culture: A Study of Japanesse and Spanish Brand Personality Constructs, Journal of Personality and Social Psychology, 81, 492-508

Akdeniz, A.A (2007).Marka ve Marka Stratejileri, 2.Baskı, Ankara: Nobel Yayın Dağıtım

Aktuğlu, I.K. (2004). Marka Yönetimi, Güçlü ve Başarılı Markalar için Temel İlkeler, İstanbul, İletişim Yayınları

Aktuğlu, I.K. \& Temel, A. (2006). Tüketiciler Markalarını Nasıl Tercih Ediyor?. Selçuk Üniversitesi Sosyal Bilimler Enstitüsü Dergisi, 15, 43-59.

Altunışık R., Özdemir Ş., Torlak Ö. (2002). Modern Pazarlama 2. Baskı, Değişim Yayınları, İstanbul

Bouslama, M.A.N.(2010). The effect of the congruence between brand personality and selfimage on consumer's satisfaction and loyalty: A conceptual framework. IBIMA Business Review, 2(2) , 34-49

Bradley, F. (1995). Marketing Management, Providing, Communicating and Delivering Value. Cambridge: Prentice Hall

Buluç, A. (2013). Konumlandırma:Al Ries ve Jack Trout. Pazarlama Biliminde 29 İnsan 29 Kavram. (Der.) Güngör M. Özgür. İstanbul: Beta Yayıncılık,159-170.

Cui, H. (2016). Parent Preferences for Baby Formula in China and Potential Implications for U.S. Dairy Product Exports Hao Cui University of Vermont Theses Dissertations

Doğanlı, B. ve Bayri, O. (2012). Süleyman Demirel Üniversitesi İktisadi ve İdari Bilimler Fakültesi Dergisi,17 (3),163-176

Durmuş, B. ,Yurtkoru, E.S. ve Çinko, M. (2011). Sosyal Bilimlerde SPSS’le Veri Analizi, Beta, İstanbul.

Girişken, Y., Bulut, D., Kurtuluş, S. (2015). Sosyal Olayların Siyasal Marka Kişiliği Üzerindeki Yansımaları, Marmara Üniversitesi İ.İ.B. Dergisi Cilt xxxv11, Sayı11, 285-306

Girişken, Y., Giray, C (2016). Vodafone's Brand Personality: A Research Related to Perception Differences between Besiktas Fans, Rival Teams' Fans and Nonsupporters. Ege Akademik Bakış 1(1), 65-78

Güneş, M., Atay, G., Şimşek, F, Uluyol, B., Suskan, E., Gülnar, S. (2003) Anne sütünün yetersiz alımına neden olan faktörler. 47. Milli Pediatri Kongresi, 3. Milli Çocuk Hemşireliği Kongresi Özet Kitabı, İstanbul, 21-23

Hollis, N. (2011). Küresel Marka, İstanbul: Brand Age Yayınları

IMS Report 2017, IMS Turkey 
İslamoğlu, H., Fırat, D. (2016). Stratejik Marka Yönetimi. Beta Basım A.Ş. İstanbul

Keller, L. K. (2003). Strategic Brand Management: Building, Measuring And Managing Brand Equity (2.ed) Pearson International Education. Londra: Prentice Hall.

Keller, L.K (2013). Strategic Brand managemet.4th edition. Pearson International Education. Londra: Prentice Hall

Köse, İ.İ , Güneş, G; Özçelikay, G. (2015) Serbest Eczanelerde Marka Kişiliği. Marmara Pharmaceutical Journal 19: 238-245

Leblebicioğlu, B., Uslu, A. (2017) Social Sciences Studies Journal Teknoloji Mağazalarının Mağaza Kişiliklerinin Karşılaştırılmasına Yönelik Bir Araştırma Social Sciences Studies Journal 3(6),1070-1082

Mark, M. \&. Pearson, C.S. (2001)The hero and the outlaw: Building extraordinary brands through the power of archetypes. McGraw Hill Professional

Mucuk, İ. (2004). Pazarlama İlkeleri, 14. Baskı, İstanbul: Türkmen Yayınevi.

Odabaşı, Y. ve Barış, G. (2013). Tüketici Davranışı, İstanbul: MediaCat Yayınları

Özçelik D. G. ve Torlak, Ö. (2011), Marka Kişiliği Algısı ile Etnosentrik Eğilimler Arasındaki İlişki: Levis ve Mavi Jeans Üzerine Bir Uygulama, Ege Akademik Bakış, 11(3), 361-377

Özer ,S. U. , Kayaalp, E.E.G. (2012). Türkiye'de Faaliyet Gösteren Havayolu Şirketlerinin Marka Kişiliklerini Belirlemeye Yönelik Bir Araştırma. Anatolia: Turizm Araştırmaları Dergisi, 23(2), Güz, 173 - 186

Şahin, Ç, (2006).Tüketicilerin Markalı Ürünlere Yönelik Olumlu Tutum ve

Davranış Geliştirmelerinde Marka Kişiliğinin Rolüne İlişkin Bir Araştırma,

Pediatrista Tezi, Karadeniz Teknik Üniversitesi Sosyal Bilimler Enstitüsü

Schiffman, L. G., \& Kanuk, L. L. (2004). Consumer behavior. Upper Saddle River, NJ: Pearson Prentice Hall.

Ünalan, P., Akgün, T., Çiftçili, S., Boler, İ., ve Akman, M. (2008) Why do mother attending a baby-friendly mother and child health care unit start early solid food to their babies. Turk Pediatri Arşivi 43,59-64

Zhang, K., Tang, L.,Wong, H.,Qiu, L.V., Binns, C.W. and Kee, A.H. (2015). Why Do Mothers of Young Infants Choose to Formula Feed in China? Perceptions of Mothers and Hospital Staff, Int. J. Environ. Res. Public Health, 12, 4520-4532

İNTERNET ADRESLERI

American Marketing Association. https://www.ama.org/resources/pages/dictionary.aspx?dLetter=B $\quad$ (erișim adresi $\underline{18.09 .2018)}$

CBME Türkiye.2017 erișim adresi http://www.cbmeturkey.com/tr/genel-bilgiler/sektoregenel-bakis) (erişim tarihi 05.12.2018)

Türkiye Nüfus ve Sağlık Araştırması 2008 www.hips.hacettepe.edu.tr/TNSA2008AnaRapor.pdf (erişim tarihi: 14.02.2018). 
Türkiyede-bebek-cocuk-sektoru. $\quad$ 05.12.2018 erişim adresi http://www.babykidstore.com/turkiyede-bebek-cocuk-sektoru-buyuyor-mu/ (erişim tarihi: 05.02.2018).

Yağcı R.V Bebeklerde Beslenme ve Devam Sütü Seçim http://www.uzmantv.com/organiksutler-anne-sutune-yakin-midir (erissim tarihi: 05.08.2018) 
Ek 1. Appetite Marka Kişiliği Faktör Analizi

\begin{tabular}{|c|c|c|c|c|c|c|c|c|c|c|c|c|c|}
\hline \multirow{2}{*}{$\begin{array}{l}\text { BOYUTLAR VE } \\
\text { MADDELER }\end{array}$} & \multirow{2}{*}{\begin{tabular}{|l} 
GÜVENILIRLiK \\
(Cronbach Alfa)
\end{tabular}} & \multicolumn{10}{|c|}{ FAKTÖR YÜKLERİ } & \multirow[t]{2}{*}{ Özdeğer } & \multirow{2}{*}{$\begin{array}{l}\text { Varyans } \\
(\%)\end{array}$} \\
\hline & & F1 & F2 & F3 & F4 & F5 & F6 & F7 & F8 & F9 & F10 & & \\
\hline \begin{tabular}{|l} 
Seçkinlik \\
\end{tabular} & 0,742 & & & & & & & & & & & 7,195 & 23,982 \\
\hline iyigorunumlu & & 0,731 & & & & & & & & & & & \\
\hline büyüleyici & & 0,718 & & & & & & & & & & & \\
\hline \begin{tabular}{|l} 
cazibeli \\
\end{tabular} & & 0,717 & & & & & & & & & & & \\
\hline genc & & 0,532 & & & & & & & & & & & \\
\hline \begin{tabular}{|l|} 
Samimiyet \\
\end{tabular} & 0,771 & & & & & & & & & & & 2,287 & 7,623 \\
\hline yararli & & & 0,848 & & & & & & & & & & \\
\hline ciddi & & & 0,746 & & & & & & & & & & \\
\hline orjinal & & & 0,697 & & & & & & & & & & \\
\hline \begin{tabular}{|l} 
samimi \\
\end{tabular} & & & 0,577 & & & & & & & & & & \\
\hline Sertlik & 0,842 & & & & & & & & & & & 2,073 & 6,911 \\
\hline \begin{tabular}{|l|} 
saglam \\
\end{tabular} & & & & 0,852 & & & & & & & & & \\
\hline dayankkh & & & & 0,828 & & & & & & & & & \\
\hline batili & & & & 0,805 & & & & & & & & & \\
\hline Neșeli & 0,792 & & & & & & & & & & & 1,999 & 6,663 \\
\hline duygusal & & & & & 0,808 & & & & & & & & \\
\hline arkadas & & & & & 0,763 & & & & & & & & \\
\hline neseli & & & & & 0,714 & & & & & & & & \\
\hline \begin{tabular}{|l|} 
Cesur \\
\end{tabular} & 0,771 & & & & & & & & & & & 1,494 & 4,981 \\
\hline moda & & & & & & 0,801 & & & & & & & \\
\hline \begin{tabular}{|l} 
heyecanverici \\
\end{tabular} & & & & & & 0,733 & & & & & & & \\
\hline cesur & & & & & & 0,659 & & & & & & & \\
\hline Cazibeli & 0,757 & & & & & & & & & & & 1,414 & 4,714 \\
\hline feminen & & & & & & & 0,796 & & & & & & \\
\hline sik & & & & & & & 0,772 & & & & & & \\
\hline sportif & & & & & & & 0,713 & & & & & & \\
\hline Zeki & 0,75 & & & & & & & & & & & 1,349 & 4,497 \\
\hline teknik & & & & & & & & 0,85 & & & & & \\
\hline kurumsal & & & & & & & & 0,81 & & & & & \\
\hline zeki & & & & & & & & 0,674 & & & & & \\
\hline Güvenilir & 0,752 & & & & & & & & & & & 1,208 & 4,028 \\
\hline caliskan & & & & & & & & & 0,83 & & & & \\
\hline \begin{tabular}{|l} 
guvenli \\
\end{tabular} & & & & & & & & & 0,81 & & & & \\
\hline guvenilir & & & & & & & & & 0,52 & & & & \\
\hline Başanlı & 0,763 & & & & & & & & & & & 1,136 & 3,787 \\
\hline lider & & & & & & & & & & 0,861 & & & \\
\hline kendineguvenen & & & & & & & & & & 0,835 & & & \\
\hline Coşkulu & 0,724 & & & & & & & & & & & 1,125 & 3,751 \\
\hline guncel & & & & & & & & & & & 0,862 & & \\
\hline essiz & & & & & & & & & & & 0,744 & & \\
\hline \begin{tabular}{|l|} 
TOPLAM \\
\end{tabular} & & & & & & & & & & & & & 70,937 \\
\hline \multicolumn{2}{|c|}{$\begin{array}{l}\text { Kaiser Meyer Olkin Yeterlilik } \\
\text { Ölçüttü }\end{array}$} & 0,766 & & & & & & & & & & & \\
\hline \multirow{3}{*}{\multicolumn{2}{|c|}{ Bartlett Testi }} & \multicolumn{2}{|c|}{ 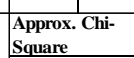 } & 2443 & & & & & & & & & \\
\hline & & df & & 435 & & & & & & & & & \\
\hline & & \begin{tabular}{|l} 
Sig. \\
\end{tabular} & & 0 & & & & & & & & & \\
\hline
\end{tabular}

